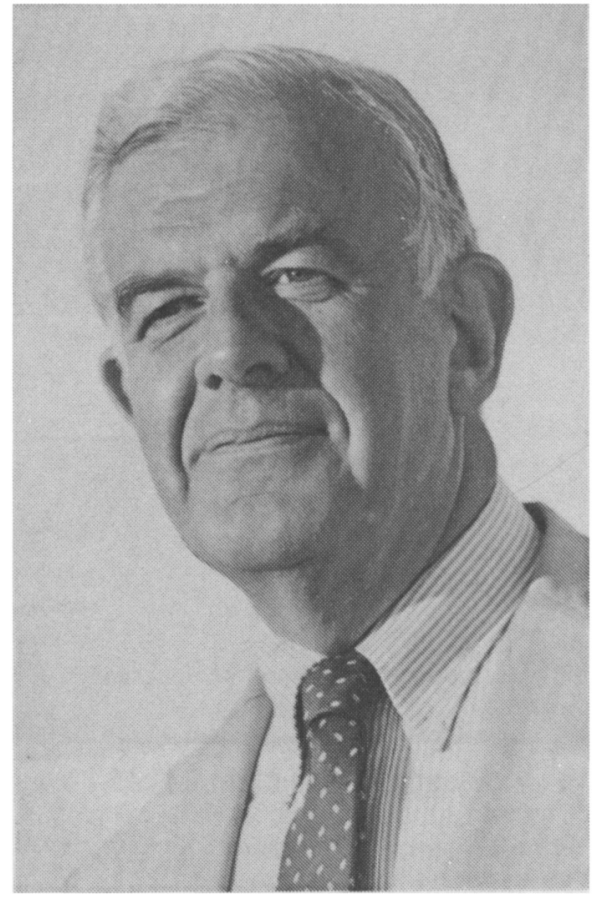

THE HONORABLE THOMAS S. FOLEY

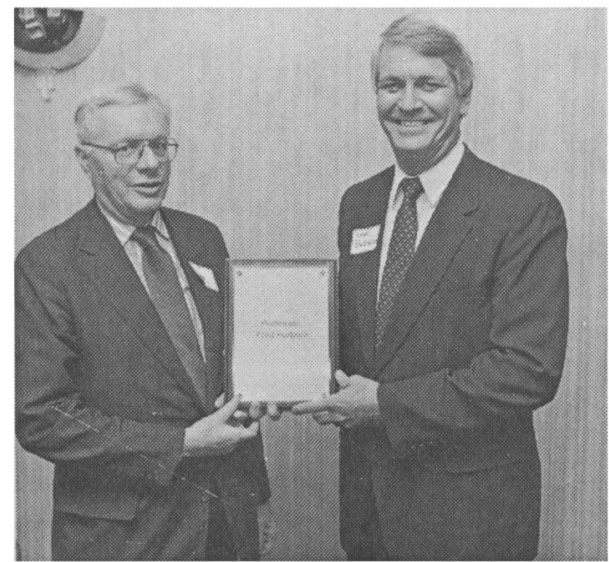

Fred Holborn accepts Congressional Fellowship Program Award from alumni association president Leonard Parkinson.

\section{Political Scientists, Reporters Named Congressional Fellows}

The APSA has announced the winners in the national competition for the 1988-89 Congressional Fellowship Program. Following a one-month orientation beginning in November, Fellows spend nine months working as legislative aides in congressional offices.

The new political science and journalism Fellows are:

\section{Political Science Fellows}

Donald C. Baumer, Associate Professor, Department of Government, Smith College.

Ardith Louise Maney, Associate Professor, Political Science Department, lowa State University.

Robert A. Strong, Associate Professor, Department of Political Science, Tulane University.

Journalism Fellows

Kenton Bird, Editorial Page Editor, Idahoian/ Palouse Empire Daily News, Moscow, Idaho, and Pullman, Washington.

William Lewis Graf, State Capitol Reporter, WISC-TV, Madison, Wisconsin. (Mr. Graf is the third recipient of the annual joan Shorenstein Barone Congressional Fellowship in Broadcast Journalism.)

Daniel R. Popkey, Reporter. The Idaho Stotesmon, Boise, Idaho.

Sponsored by the Association since 1953, the purpose of the Congressional Fellowship Program is to give outstanding political scientists, journalists, medical faculty, and federal agency executives an opportunity to acquire a rich understanding of the national legislative process.

The 1,256 alumni of the program include university presidents, deans, and professors, newspaper and magazine publishers, editors and reporters, senior-level executives in the federal government, and congressmen and congressional staff aides.

Other participants in the 1988-89 program will include: 


\section{Association News}

\section{Carl Albert Fellow}

L. Marvin Overby, Ph.D. Candidate, Political Science, University of Oklahoma.

\section{Asian Fellows}

Armin Effendi bin Abdul Rahman, Research Assistant to Director General, Institute of Strategic and International Studies, Malaysia.

Liu Linfei, People's Republic of China, Visiting Scholar in International Relations and American Government at The Johns Hopkins University School of Advanced International Studies.

Chirachai Punkrasin, Soviet Desk Officer, Department of Political Affairs, Ministry of Foreign Affairs, Government of Thailand.

\section{French Fellow}

Marie-Pascale Boutry, Administrator, Committee Services, French Senate.

\section{West German Fellows}

Hans-Joachim Christe, M.A., Political Science, University of Tubingen, West Germany; former Bundestag Staff Member.

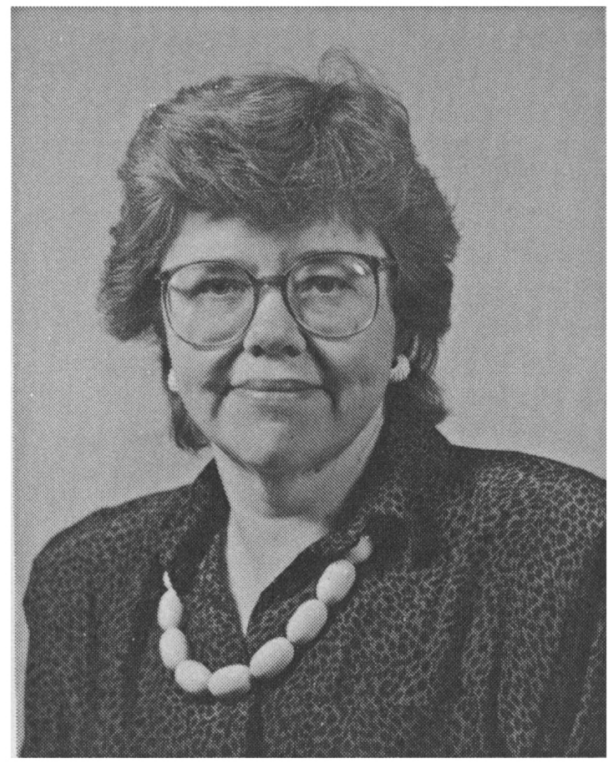

ARDITH LOUISE MANEY

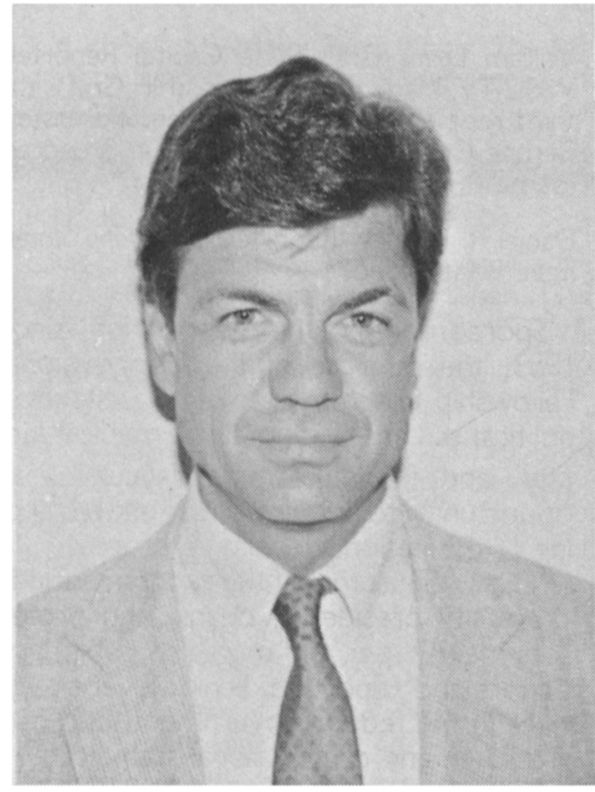

DONALD C. BAUMER

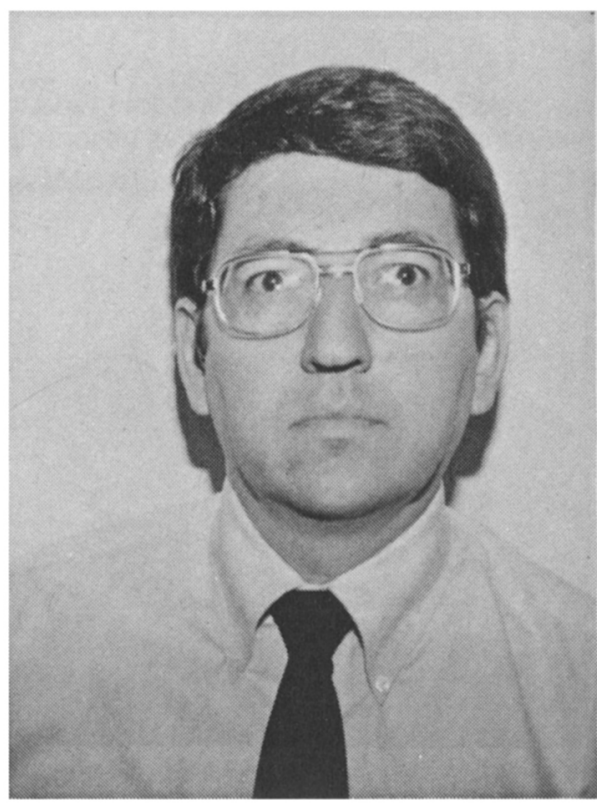

ROBERT A. STRONG 
Reinhard Kowalewsky, Ph.D. Candidate, Political Science, University of Cologne, West Germany.

\section{American Society of \\ Allied Health Professions (Kellogg Health Policy Fellow)}

Louise Little, Associate Professor. Human Nutrition and Acting Chair. Department of Nutrition and Dietetics, University of Delaware.

\section{Robert Wood Johnson Health Policy Fellows}

Ann B. Flood, Ph.D., Associate Professor, Medical Humanities and Social Sciences Program. The University of Illinois College of Medicine at Urbana-Champaign.

Barbara E. Langner, Ph.D., R.N., Associate Professor, The School of Nursing, College of Health Sciences, The University of Kansas Medical Center.

Joel S. Levine, M.D., Associate Professor, Department of Medicine, School of Medicine, University of Colorado Health Sciences Center.

Joseph A. Lieberman III, M.D., Professor and Chairman, Department of Family Medicine, Robert Wood Johnson Medical School, Univer. sity of Medicine and Dentistry of New Jersey.

Ridrigue Mortel, Professor and Chairman, Department of Obstetrics and Gynecology, The Milton S. Hershey Medical Center, The Pennsylvania State University.

Anthony Schwartz, D.V.M., Ph.D. Professor and Chairman, Department of Surgery. Tufts University School of Veterinary Medicine.

\section{Federal Fellows}

William J. Andahazy, Supervisory Physicist, David Taylor Naval Ship Research and Development Center, Department of the Navy.

Thomas ]. Bond, Trust Services Officer, Eastern Area Office, Bureau of Indian Affairs, Department of the Interior.

Elizabeth L. Doolittle, Technical Assistant, Nuclear Regulatory Commission.

James $H$. Edgar, Jr., Chief, Acquisition Civilian Career Enhancement Program, Department of the Air Force.

Nancy F. Green, Endangered Species Program Manager, Forest Service, Department of Agriculture.

Anthony T. Hawkins, Director, Correspon- dence Management Staff, Veterans Administration.

Richard $O$. Miller, Chief, Regulatory Development and Issues Management Staff, Office of Surface Mining Reclamation and Enforcement, Department of the interior.

Alan L. Moss, Director, Division of Wage Determinations, Employment Standards Administration, Department of Labor.

Ralph C. Rosacker, Major, Branch Head, Personnel Procurement Division, Manpower Department, U.S. Marine Corps, Department of the Navy.

David A. Rutherford, Branch Chief, Employment Standards Administration, Department of Labor.

June C. Schaeffer, Assistant Director for Education Policy and Program Administration, Vocational Rehabilitation and Education Service, Veterans Administration.

Kenneth L. Sichel, Section Chief, Operations Directorate, National Security Agency.

Charles P. Weber, Investigator, Division of Elections and Trusteeships, Office of LaborManagement Standards, Department of Labor.

\section{Foreign Affairs Fellows}

James P. Callahan, Senior El Salvador Desk Officer, Department of State.

Randy D. Ferryman, Branch Chief, Central Intelligence Agency.

Douglas Hengel, Economic Officer, Department of State.

Christopher R. Hill, Finance and Development Officer, Department of State.

Vicki f. Huddleston, Country Officer for Bolivia, Department of State.

William B. Loper, Major, Personnel Management Officer, Department of the Army.

Timothy A. Peterson, Major, Battalion Operations Officer, Department of the Army.

Gary D. Smith, Branch Public Affairs Officer, Department of State.

Charles F. Turgeon, Division Chief, Resource Planning \& Management Center, Central Intelligence Agency.

Charles J. Wells, Intelligence Officer (Policy), Defense Intelligence Agency.

Howard C. Wiener III, Personnel Planning Officer, Office of the Director General of the Foreign Service, Department of State. 